\title{
Differential regulation of follicle stimulating hormone by activin $A$ and TGFB I in murine gonadotropes
}

\author{
A Jesse Gore ${ }^{1}$, Daniel P Philips ${ }^{2}$, William L Miller ${ }^{1}$ and Daniel J Bernard*2,3
}

Address: ${ }^{1}$ Department of Molecular and Structural Biochemistry, Box 7622, North Carolina State University, Raleigh, NC 27695-7622, USA, ${ }^{2}$ Center for Biomedical Research, Population Council, 1230 York Ave., New York, NY 10021, USA and 3 The Rockefeller University, 1230 York Ave., New York, NY 10021, USA

Email: A Jesse Gore - ajgore@ncsu.edu; Daniel P Philips - dan.philips@verizon.net; William L Miller - bill_miller@ncsu.edu; Daniel J Bernard* - dbernard@popcbr.rockefeller.edu

* Corresponding author

Published: 29 December 2005

Reproductive Biology and Endocrinology 2005, 3:73 doi:10.1186/1477-7827-3-73

This article is available from: http://www.rbej.com/content/3/I/73

(C) 2005 Gore et al; licensee BioMed Central Ltd.

This is an Open Access article distributed under the terms of the Creative Commons Attribution License (http://creativecommons.org/licenses/by/2.0), which permits unrestricted use, distribution, and reproduction in any medium, provided the original work is properly cited.
Received: 02 November 2005

Accepted: 29 December 2005

\begin{abstract}
Background: Activins stimulate the synthesis of follicle stimulating hormone (FSH) in pituitary gonadotropes, at least in part, by inducing transcription of its beta subunit (Fshb). Evidence from several laboratories studying transformed murine LbetaT2 gonadotropes indicates that activins signal through Smad-dependent and/or Smad-independent pathways, similar to those used by transforming growth factor beta-I (TGFBI) in other cell types. Therefore, given common intracellular signaling mechanisms of these two ligands, we examined whether TGFBs can also induce transcription of Fshb in LbetaT2 cells as well as in purified primary murine gonadotropes.
\end{abstract}

Methods: Murine Fshb promoter-reporter (-1990/+I mFshb-luc) activity was measured in LbetaT2 cells treated with activin A or TGFBI, and in cells transfected with either activin or TGFB receptors. The ability of the ligands to stimulate phosphorylation of Smads 2 and 3 in LbetaT2 cells was measured by western blot analysis, and expression of TGFB type I and II receptors was assessed by reverse transcriptase polymerase chain reaction in both LbetaT2 cells and primary gonadotropes purified from male mice of different ages. Finally, regulation of endogenous murine Fshb mRNA levels by activin A and TGFBI in purified gonadotropes and whole pituitary cultures was measured using quantitative RT-PCR.

Results: Activin A dose-dependently stimulated - 1990/+I mFshb-luc activity in LbetaT2 cells, but TGFBI had no effect at doses up to $5 \mathrm{nM}$. Similarly, activin A, but not TGFBI, stimulated Smad 2 and 3 phosphorylation in these cells. Constitutively active forms of the activin (Acvrlb-T206D) and TGFB (TGFBRI-T204D) type I receptors strongly stimulated - I990/+I mFshb-luc activity, showing that mechanisms down stream of Tgfbrl seem to be intact in LbetaT2 cells. RT-PCR analysis of LbetaT2 cells and whole adult murine pituitaries indicated that both expressed Tgfbrl mRNA, but that Tgfbr2 was not detected in LbetaT2 cells. When cells were transfected with a human TGFBR2 expression construct, TGFBI acquired the ability to significantly stimulate - 1990/+I mFshb-luc activity. In contrast to LbetaT2 cells, primary murine gonadotropes from young mice (8-10 weeks) contained low, but detectable levels of Tgfbr2 mRNA and these levels increased in older mice ( 1 yr). A second surprise was the finding that treatment of purified primary gonadotropes with TGFBI decreased murine Fshb mRNA expression by $95 \%$ whereas activin $A$ stimulated expression by $3 \mathrm{I}$-fold.

Conclusion: These data indicate that TGFBI-insensitivity in LbetaT2 cells results from a deficiency in Tgfbr2 expression. In primary gonadotropes, however, expression of Tgfbr2 does occur, and its presence permits TGFBI to inhibit Fshb transcription, whereas activin A stimulates it. These divergent actions of activin A and TGFBI were unexpected and show that the two ligands may act through distinct pathways to cause opposing biological effects in primary murine gonadotropes. 


\section{Background}

Follicle-stimulating hormone (FSH) synthesis, secretion, and action are critical for reproductive function in mammals, particularly in females [1-3]. FSH production is regulated by a variety of neuroendocrine, intra-pituitary, and gonadal factors. Arguably, the most potent and selective stimulators of FSH synthesis are the activins, members of the transforming growth factor beta (TGFB) superfamily. Within the anterior pituitary, activins (activin B, in particular) act in paracrine/autocrine fashion to induce expression of the FSH beta (Fshb) subunit [4-9], the rate-limiting step in mature FSH production.

Several other factors that regulate FSH synthesis appear to have their actions via synergy with or perturbation of endogenous activin signaling. For example, activins synergistically stimulate rat and sheep Fshb transcription with gonadotropin releasing hormone (GNRH1) via cross-talk between activin and GNRH1 signaling pathways as well as through regulation of GNRH1 receptor expression [1013]. Testicular androgens regulate Fshb transcription both directly and indirectly, although these effects vary across species [14]. In sheep, the direct actions of androgens on transcription appear to require intact activin signal transduction mechanisms [15]. Follistatins (FST) inhibit FSH production by binding activins and blocking the latter from interacting with their cell surface receptors [16,17]. Similarly, gonadal inhibins suppress FSH synthesis via antagonism of activins; in this case through competition with activins for binding to activin type II receptors [1822]. Thus, many of the endocrine and paracrine factors known to affect FSH production do so through an interaction with or disruption of activin signaling. These and other data [23-25] indicate that the activins are critical for normal FSH regulation.

Both activins and TGFBs bind hetero-tetrameric receptor complexes consisting of ligand specific type I and type II receptor serine/threonine kinases $[26,27]$. Activins bind one of two type II receptors, ACVR2A or ACVR2B, which then recruit and phosphorylate the activin type IB receptor, ACVR1B or ALK4. In analogous fashion, TGFB1 binds TGFBR2, which recruits and phosphorylates TGFBR1 (also known as ALK5). Once activated, ACVR1B and TGFBR1 can phosphorylate Smad2 and Smad3 on C-terminal serine residues $[28,29]$, and can also activate TGFBactivated kinase 1 (TAK1) [30,31]

In rodents, activins stimulate Fshb subunit gene transcription through both immediate-early and indirect (delayed or late) signaling pathways [30,32-34]. There is evidence to implicate Smads in Fshb gene transcription because they are rapidly phosphorylated and trans-located to the nucleus rapidly following activin A treatment [32,35-37]. In rats and mice, interference with Smad2 or Smad3 sign- aling impairs activin A-regulated Fshb transcription $[13,32,33,35,37]$. However, these proteins seem to play less important roles in activin A-induced Fshb transcription in sheep and humans $[30,33]$, where Smad-independent mechanisms mediated by TGFB-activated kinase 1 (TAK1) appear to be critical for the former.

Like activins, the TGFB isoforms 1, 2, and 3 also phosphorylate and activate Smad2, Smad3 and TAK1 [28,29,31]. TGFB1 is produced within rat pituitary lactotropes $[38,39]$. Therefore, it is possible that TGFBs, acting in a paracrine manner, may also stimulate rodent $F s h b$ transcription in gonadotropes via a similar $S \operatorname{mad} 2 / 3$ - and/or TAK1-dependent mechanism. If this occurs, however, how could gonadotrope cells discriminate intracellularly between activin and TGFB-generated signals, specifically with respect to FSH regulation? This is an important question, in light of the fact that various physiological mechanisms that have evolved to spatially and temporally restrict activin's actions do not affect TGFB signaling $[16,40]$. For example, ovarian inhibin B production and action during metestrus and diestrus are critical for the suppression of activin-stimulated FSH production at these times of the rat estrous cycle $[41,42]$. Inhibin B may play a similar role during the follicular phase of the human menstrual cycle $[43,44]$. In addition, FST is dynamically regulated in the pituitary across the rat estrous cycle and its patterns of expression appear to be critical for the proper timing of the secondary FSH surge on the morning of proestrus $[45,46]$. Neither the inhibins nor FST suppress TGFB1 actions [19,47-49]. Therefore, antagonism of activins' stimulation of FSH by these proteins could theoretically be circumvented by unfettered TGFB1 stimulation of Smad2/3- and/or TAK1-dependent signaling mechanisms. We, therefore, examined TGFB1-regulated expression of murine Fshb subunit transcription to determine whether or not gonadotropes have evolved a mechanism to discriminate between the activin and TGFB ligands.

\section{Methods \\ Reagents and constructs}

Human recombinant (rh-) TGFB1, rh-activin A, recombinant mouse (rm)-follistatin 288 were purchased from R\&D systems (Minneapolis, MN). Dulbecco's modified Eagle medium (DMEM), Lipofectamine/Plus, Lipofectamine 2000, gentamycin, and Trizol were from Invitrogen (Carlsbad, CA). Fetal bovine serum (FBS) was from JRH Biosciences (Lenexa, KS). The anti-Smad3 affinity purified rabbit polyclonal antibody was purchased from Zymed (South San Francisco, CA). Anti-Smad2/3 and phospho-Smad2 affinity purified rabbit polyclonal antibodies were purchased from Upstate Biotech (Waltham, MA). The phospho-Smad3 rabbit polyclonal antibody was a generous gift of Dr. Michael Reiss (Robert Wood 
Johnson Medical School). Protease inhibitor tablets (CompleteMini) were purchased from Roche (Indianapolis, IN). Deoxynucleotide triphosphates (dNTPs), MMLV reverse transcriptase, random primer hexamers, and Taq polymerase were from Promega (Madison, WI). The 1990/+1 mFshb-luc reporter and constitutively active HArat ALK4 (Acvr1b) were described previously [32]. HAhuman TGFBR1(T204D) was provided by Dr. Peter Scheiffele (Columbia University). The 3TP-luc reporter and HA-human TGFBR2 expression construct were gifts of Dr. Joan Massague (Memorial Sloan Kettering Cancer Center).

\section{Primary gonadotropes}

Pituitaries from mice containing the ovine FSHB- $H 2 K^{K}$ transgene were used for gonadotrope purification. Young mice (8-10 weeks old; $10-18$ mice) or older mice (1 year old; 12 mice) were killed and their pituitaries were dispersed and the gonadotropes were purified as reported [50]. Cells that did not attach to the magnetic column were labeled "gonadotrope-depleted," while cells eluted from the column after removal of the magnetic field were labeled "gonadotropes." Cell counts were obtained for all cell types using a hemocytometer. Equal numbers of cells were cultured in medium 199 (Gibco) with 10\% charcoaltreated sheep serum and antibiotics/antimycotics as reported [51]. Gonadotropes and gonadotrope-depleted cells purified from younger mice were plated in triplicate at a density of 18,000 cells per well (first experiment) or 30,000 cells per well (second and third experiments). Cells isolated from older mice were plated in triplicate at a density of 50,000 cells per well in two separate experiments. For treatments with activin A or TGFB1, purified gonadotropes or whole pituitary cells were plated in triplicate at a density of 10,000 cells per well in three separate experiments. Gonadotropes, gonadotrope-depleted cells, and whole pituitary cells were cultured in $200 \mu \mathrm{l}$ of media in 96 well Primaria culture plates (Becton Dickinson \& Co, Franklin Lakes, NJ). Cells were incubated at $37^{\circ}$ under $5 \% \mathrm{CO}_{2}$ for $48 \mathrm{hrs}$ prior to RNA isolation. All mice were handled in accordance with the rules and regulations of the Institutional Animal Care and Use Committee of North Carolina State University.

\section{Cell culture and transfection}

Immortalized murine gonadotrope L $\beta \mathrm{T} 2$ cells were provided by Dr. Pamela Mellon (University of California, San Diego) and were cultured as described previously [32]. Murine fibroblast NIH3T3 cells were obtained from Dr. Patricia Morris (Population Council) and were cultured in DMEM/10\% FBS. Cells were plated in 6- or 24-well plates at densities of $1 \times 10^{6}$ or $2 \times 10^{5}$ cells per well, respectively, approximately $36 \mathrm{hr}$ prior to transfection. Cells were transfected with Lipofectamine/Plus or Lipofectamine 2000 following the manufacturer's instructions. Reporter plasmids were transfected at $1 \mu \mathrm{g}$ (6-well) or $450 \mathrm{ng}$ (24well) per well. Expression plasmids were introduced at $300 \mathrm{ng}$ (24-well) per well. In all experiments, the total amount of DNA added was balanced across treatments with empty expression vector pcDNA3.0 (Invitrogen).

In reporter experiments including ligand treatment, activin A or TGFB1 were added at the indicated concentrations for approximately $24 \mathrm{hr}$. Cells were washed with $1 \times$ PBS and lysed in $1 \times$ Passive Lysis Buffer (Promega). Luciferase assays were performed on a Luminoskan Ascent luminometer (Thermo Labsystems, Franklin, MA) as described [32]. All transfection conditions were performed in triplicate and each experiment performed 2-3 times.

\section{Western blotting}

L $\beta$ T2 and NIH3T3 cells were seeded at 7 or $4 \times 10^{5}$ cells per well, respectively, in 6-well plates. After $24-48 \mathrm{hr}$., cells were washed with serum-free DMEM and then incubated in the same medium overnight. The following day, cells were treated with the indicated concentrations of activin A or TGFB1 in fresh serum-free DMEM for $1 \mathrm{hr}$. After a wash with PBS, whole cell lysates prepared in RIPA buffer containing protease inhibitors. Equivalent amounts of protein were separated by $8 \%$ Tris-glycine SDS-PAGE and transferred to Protran (Schleicher \& Schuell, Keene, NH). Filters were probed with anti-phospho-Smad2, anti-phospho-Smad3, anti-Smad2/3, or antiSmad3 using previously described methods [32].

\section{Semi-quantitative RT-PCR}

Total RNA was extracted from adult female CD-1 murine pituitaries and L $\beta$ T2 cells using Trizol following the manufacturer's instructions. Four $\mu \mathrm{g}$ of total RNA were reverse transcribed (RT) into cDNA using $100 \mathrm{ng}$ random hexamer primers and $100 \mathrm{U}$ MMLV-RT. A second set of samples was processed similarly, except the RT enzyme was omitted (no RT) as a control for contaminating genomic DNA in the RNA samples. One-tenth of each RT or RTreaction was used as template in PCRs for Tgfbr1 (503 bp) and Tgfbr2 (536 bp). PCR was run using the following conditions for 35 cycles: 94C for $30 \mathrm{sec}, 53 \mathrm{C}$ for $30 \mathrm{sec}$, and $72 \mathrm{C}$ for $30 \mathrm{sec}$. Reactions contained $0.4 \mathrm{pmol}$ of each primer, $200 \mu \mathrm{M}$ dNTPs, $1.5 \mathrm{mM} \mathrm{MgCl}_{2}, 1 \times$ PCR buffer, and 2.5 U Taq polymerase. Following a final $7 \mathrm{~min}$. extension step at $72 \mathrm{C}$, one-fifth of each reaction was resolved on a $1 \%$ agarose gel containing ethidium bromide. Gels were photo-documented using a digital camera interfaced with an IBM ThinkPad computer running the Kodak Digital Science 1D software (v.2.0.2) software. Reactions with no template $\left(\mathrm{H}_{2} \mathrm{O}\right.$ only) were used to confirm the absence of contaminating DNA in the reagents. The primer sets for Tgfbr 1 and Tgfbr2 were as follows: Tgfbr1, (forward) AACCTGTTGTATTGCAGACTT and (reverse) GAGCAGAGT- 
Table I: Real Time RT-PCR primer and probe sequences

\begin{tabular}{|c|c|c|}
\hline Primer/Probe Set & & Sequence \\
\hline \multirow[t]{3}{*}{ Tgfbrl } & Forward & 5': CATTCACCACCGTGTGCCAAATGA \\
\hline & Reverse & 5': ACCTGATCCAGACCCTGATGTTGT \\
\hline & Probe & 5': AGATCGCCCTTTCATTTCAGAGGGCA \\
\hline \multirow[t]{3}{*}{ Tgfbr2 } & Forward & 5': TCCCAAGTCGGATGTGGAAATGGA \\
\hline & Reverse & 5': TCGCTGGCCATGACATCACTGTTA \\
\hline & Probe & $\begin{array}{l}\text { 5': } \\
\text { AGCCCAGAAAGATGCATCCATCCACGTA }\end{array}$ \\
\hline \multirow[t]{3}{*}{ Prolactin } & Forward & 5': TCTCAAGGTCCTGAGGTGCCAAAT \\
\hline & Reverse & 5': CCATTGCACCCAAGCATGCACTGA \\
\hline & Probe & $\begin{array}{l}\text { 5': } \\
\text { ACAACTGCTAAACCCACATTCAGTCCA }\end{array}$ \\
\hline \multirow[t]{3}{*}{ Fshb } & Forward & 5': AGAGAAGGAAGAGTGCCGTTTCTG \\
\hline & Reverse & 5': ACATACTTTCTGGGTATTGGGCCG \\
\hline & Probe & 5': ATCAATACCACTTGGTGTGCGGGCTA \\
\hline \multirow[t]{3}{*}{ I8s rRNA } & Forward & 5': GAAACTGCGAATGGCTCATTAA \\
\hline & Reverse & 5': GAATCACCACAGTTATCCAAGTAGGA \\
\hline & Probe & 5': ATGGTTCCTTTGGTCGCTCGCTCC \\
\hline
\end{tabular}

\section{TCCCACGGTGT; Tgfbr2, (forward) TTGCCTGTGTGACTTCGGGCT and (reverse) CTATTT- GGTAGTGTTCAGCGA.}

\section{Real-Time RT-PCR (RT-rtPCR)}

Total RNA from primary and L $\beta$ T2 cells was isolated and converted to cDNA as reported [51]. Oligonucleotides for Taqman real-time PCR were designed for murine cDNA using software from Integrated DNA Technologies, Inc (Coralville, IA) for Tgfbr1, Tgfbr2, Fshb and prolactin (Table 1). Using the same oligonucleotides as described previously [50], murine $18 \mathrm{~s}$ ribosomal RNA served as the endogenous control. All Taqman probes were 5' -labeled with FAM and real-time PCR of all cDNA samples was performed at the same time. Real-time PCR was performed in duplicate on triplicate cDNA samples from both gonadotropes and gonadotrope-depleted cells using an iCycler (Bio-Rad, Inc). Samples were incubated at $95^{\circ} \mathrm{C}$ for 3 min, and then for 40 complete cycles $\left(95^{\circ} \mathrm{C}\right.$ for $30 \mathrm{sec}$, $55^{\circ} \mathrm{C}$ for $30 \mathrm{sec}$, and $72^{\circ} \mathrm{C}$ for $30 \mathrm{sec}$ ). There was a final extension step of $72^{\circ} \mathrm{C}$ for $3 \mathrm{~min}$. Threshold cycle $\left(\mathrm{C}_{\mathrm{T}}\right)$ values were determined with Bio-Rad software and used for relative quantitation with the $2^{-\Delta \Delta \mathrm{Ct}}$ method [52].

\section{Statistical analysis}

The data from replicate luciferase assay experiments were highly similar and were pooled ( $n=6$ or 9 per treatment) for statistical analyses. Data are presented as fold-change from the control condition in each experiment. Differences between means were compared using one- or twoway analyses of variance followed by post-hoc Scheffe or Bonferroni tests (Systat 10.2, Richmond, CA). Comparisons of relative receptor mRNA expression in gonadotrope and gonadotrope-depleted cells in different age groups were performed with two-way ANOVAs of log- transformed data. Fshb mRNA levels were compared in one-way ANOVAs of log-transformed data. In all cases, significance was assessed relative to $p<0.05$.

\section{Results \\ Activin A but not TGFB I, stimulated Fshb transcription in L $\beta$ T 2 cells}

L 3 T2 cells were transfected with a murine $-1990 /+1$ Fshb luciferase promoter-reporter construct $(-1990 /+1 \mathrm{mFSHB}$ luc) [32] and were treated with different concentrations of activin A or TGFB1 for approximately $24 \mathrm{hr}$. Whereas activin A dose-dependently stimulated reporter activity, TGFB1 had no effect at concentrations up to $5 \mathrm{nM}$ (Fig. 1A). In addition, activin A, but not TGFB1, stimulated Smad 2 and 3 phosphorylation in these cells (Fig. 1B). In contrast, the same lot of TGFB1 at lower concentrations (4-400 pM) dose-dependently stimulated the activin/ TGFB responsive promoter of 3TP-luc [53], and Smad2/3 phosphorylation in murine NIH3T3 fibroblast cells (Figs. $2 \mathrm{~A}$ and 2B). Thus, the TGFB1 ligand was biologically active, but L $\beta \mathrm{T} 2$ cells were somehow insensitive to it.

\section{Constitutively active activin and TGFB type I receptors stimulated Fshb transcription in $L \beta T 2$ cells}

We previously showed that a constitutively active form of rat Acvr1b (T206D), which can stimulate Smad phosphorylation in the absence of activins and the type II receptors [54], stimulated murine Fshb promoter-reporter activity [32]. Here, we asked whether a constitutively active form of TGFBR1 (T204D; [55]) could similarly stimulate Fshb transcription in L $\beta$ T2 cells. As shown in Figure 3, both rat Acvr1b-TD and human TGFBR1-TD potently stimulated 1990/+1 mFshb-luc. These data indicate that events downstream of TGFBR1 (whether Smad-dependent or Smadindependent; $[30,56])$ seem to be present in L $\beta$ T2 cells 
and therefore that the cells' insensitivity to TGFB1 likely derives from a deficiency at the receptor level.

L $\beta T 2$ cells do not express the TGFB type II receptor, Tgfbr2 We used RT-PCR to examine Tgfbr 2 and Tgfbr1 mRNA levels in LBT2 cells compared to adult murine pituitary glands. Whereas both L $\beta \mathrm{T} 2$ cells and pituitary glands expressed Tgfbr1 mRNA, only the latter expressed Tgfbr2 (Fig. 4).

\section{Over-expression of TGFBR2 in L $\beta T 2$ cells conferred TGFB I responsiveness in $L \beta T 2$ cells}

RT-PCR analysis indicated that L 3 T2 cells do not express Tgfbr2 mRNA. Therefore, these cells may not respond to TGFB1 because of a deficiency in this receptor. It is possible, however, that additional mechanisms contribute to TGFB1 insensitivity. To address this issue, we transfected L $\beta$ T2 cells with a human TGFBR2 expression construct and examined TGFB1-stimulated Fshb transcription. Over-expression of the receptor alone had no effect on basal transcription, but made it possible for TGFB1 to stimulate $-1990 /+1 \mathrm{mFshb}$-luc activity (Fig. 5). Therefore, a deficiency in Tgfbr 2 expression appeared to account for the inability of LBT2 cells to respond to TGFB1.

\section{Primary murine gonadotropes exhibit low Tgfbr2 expression}

L $\beta$ T2 cells were derived from a pituitary tumor in a female transgenic mouse [57]. Whereas these cells show many of the features of fully differentiated gonadotropes, they are transformed cells and exhibit clear differences from gonadotropes in vivo. For example, basal Fshb expression is substantially lower in L $\beta$ T2 cells than in gonadotropes (personal observations). Therefore, it is possible that the Tgfbr2-deficiency observed in L $\beta \mathrm{T} 2$ cells may not accurately reflect receptor expression in gonadotropes in vivo, though previous analyses in rats indicated that within the pituitary, Tgfbr2 expression is most abundant in lactotropes $[58,59]$. In order to examine receptor expression in murine gonadotropes, we purified this cell type from male mice, aged eight to ten weeks (young) or 1 year of age (old), using a recently described transgenic model [50]. Using real-time RT-PCR, prolactin ( $\mathrm{Prl}$ ) expression was examined to determine the level of purification of the gonadotropes from mixed primary pituitary cultures as described earlier [50]. The level of purity ranged from 97 $\%$ to $99 \%$ (data not shown).

We then measured Tgfbr1 and Tgfbr 2 mRNAs using realtime RT-PCR. Tgfbr1 mRNA was significantly higher in older than younger animals $(p<0.001)$, but did not differ significantly between gonadotropes and gonadotropedepleted cells, nor was there a significant interaction between these two variables (Fig. 6A). In contrast to L $\beta$ T2 cell data, Tgfbr2 mRNA was detected in gonadotropes but
A

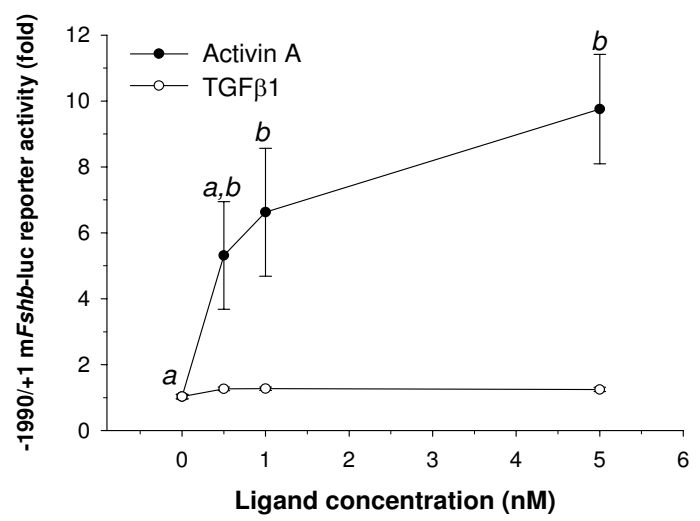

B

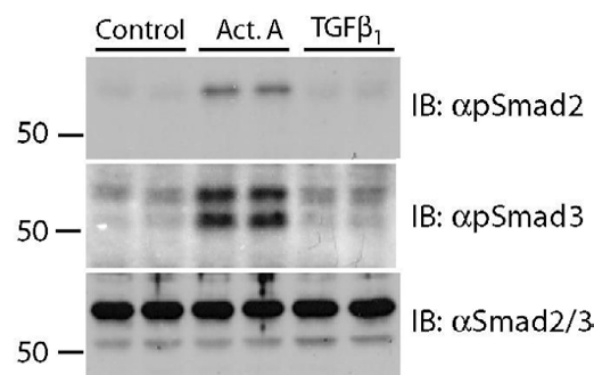

Figure I

TGFB I fails to stimulate Fshb transcription or Smad2/3 phosphorylation in L $\beta$ T2 cells. A) L $\beta$ T2 cells were seeded in 6-well plates and transfected with the murine $-1990 /+1$ mFshb-luc reporter. Following transfection, cells were treated with the indicated concentrations of activin $A$ (closed circles) or TGFBI for approximately 24 hours. Lysates were subjected to luciferase assays. Data points reflect mean (+/-SEM) fold-change in luciferase activity from the control condition $(0 \mathrm{nM})$ in two experiments performed in triplicate $(n=6)$. Points with different letters differed significantly. B) L $\beta$ T2 cells seeded in 6-well plates were treated with vehicle (control), I.2 nM activin A or TGFBI for I hour. Immunoblots (IB) of whole cell lysates were probed with rabbit anti-phospho-Smad2 (top), anti-phospho-Smad3 (middle), or anti-Smad2/3 (bottom) antibodies. Treatments were performed in duplicate. Numbers at the left are molecular weight standards in $\mathrm{kDa}$.

it was greater in older than younger animals $(p<0.001)$. Tgfbr2 mRNA was also higher in gonadotrope-depleted cells than pure gonadotropes across both age groups $(p<$ 0.007) (Fig. 6B). In young mice, gonadotrope-depleted cells expressed Tgfbr2 6.5-fold higher than purified gonadotropes, whereas in the old mice the difference was reduced to 2.2-fold, but the interaction between cell type and age was not statistically significant. In the same assays, Tgfbr2 was undetectable in L $3 \mathrm{~T} 2$ cells, and Tgfbr1 
in LBT2 cells was expressed at roughly $20 \%$ of Tgfbr 1 in purified gonadotropes in young animals (data not shown).

\section{Activin A increased, and TGFBI decreased, Fshb mRNA levels in murine gonadotropes and whole murine pituitary cultures}

Because purified gonadotropes express $T g f b r 2$, we used real-time RT-PCR to examine the effects of activin A and TGFB1 on endogenous Fshb mRNA levels. Treatment of purified gonadotropes from younger mice with activin A resulted in a 31-fold stimulation of Fshb mRNA (Fig. 7A). Surprisingly, treatment with TGFB1 resulted in a significant $95 \%$ reduction in Fshb mRNA levels (Fig. 7A). Similar results were obtained in gonadotropes isolated from older mice (data not shown). Importantly, treatment with TGFB1 did not appear to affect cell viability since there were no differences in the levels of $18 \mathrm{~s}$ rRNA between control and treated cells (data not shown), and no morphological changes of treated cells relative to control were observed (personal observations). In whole pituitary cultures, activin A and TGFB1 exerted similar effects on Fshb expression to those seen in purified gonadotropes, although their magnitudes were reduced (Fig. 7B). Activin A induction was 19.5 -fold, and inhibition by TGFB1 was only $56 \%$ and was not statistically significant $(p=0.175$, Scheffe post-hoc). Therefore, unlike L $\beta T 2$ cells, primary murine gonadotropes are sensitive to TGFB1 and the ligand inhibits Fshb mRNA levels, perhaps by repressing transcription.

\section{Discussion}

Activins regulate rodent and ovine Fshb transcription via Smad2/3- and/or TAK1-dependent intracellular signaling pathways $[13,30,32,33,35,37,60]$. Although TGFB isoforms also activate these pathways, we found that TGFB1 fails to regulate murine Fshb transcription in L $\beta T 2$ cells, apparently because they do not express the TGFB type II receptor, Tgfbr2. However, when the cells were transiently transfected with the receptor, TGFB1 stimulated murine Fshb transcription. In striking contrast, we observed that gonadotrope cells purified from male mice expressed low levels of Tgfbr 2 mRNA and that TGFB1 suppressed Fshb mRNA in these cells as well as in mixed murine pituitary cell cultures. Because over-expression of TGFBR2 allowed TGFB1 to stimulate the $-1990 /+1 \mathrm{mFshb}$-luc construct in L $\beta T 2$ cells, differences in TGFB1 responses observed between the cell line and purified gonadotropes do not appear to be attributable to differences in Tgfbr 2 expression. Instead, the mechanisms through which TGFB1 inhibits Fshb expression in gonadotropes may be absent from L $\beta$ T2 cells.

The identity of these inhibitory mechanisms is currently unknown, though opposing actions of activin A and

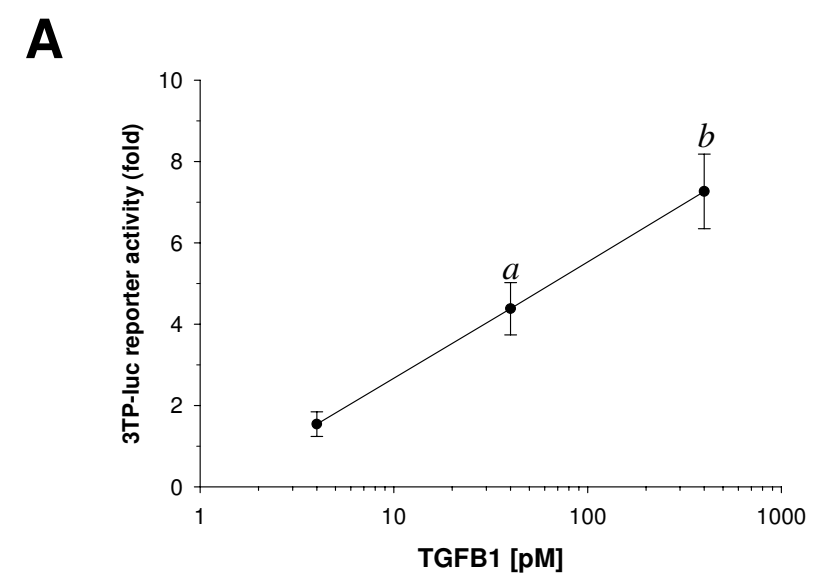

B

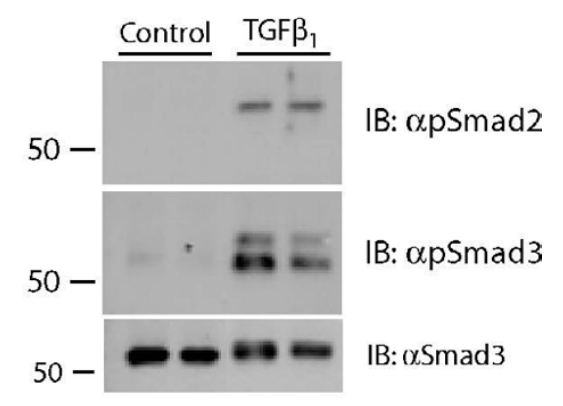

\section{Figure 2}

TGFB I stimulates 3TP-luc activity and Smad2/3 phosphorylation in NIH3T3 cells. A) Murine fibroblast $\mathrm{NIH} 3 \mathrm{~T} 3$ cells were seeded in 24-well plates and transfected with the TGFB responsive promoter-reporter 3TP-luc. Following transfection, cells were treated with 4-400 pM TGFBI for approximately 24 hours. Luciferase assays were performed as described. Data points reflect mean (+/- SEM) fold-change in luciferase activity from the control condition ( 0 PM, not pictured) in two experiments performed in triplicate $(n=6)$. The data are presented on a log-linear plot. Points with letters differed from control and points with different letters differed from one another. B) NIH3T3 cells seeded in 6-well plates were treated with vehicle (control) or 400 pM TGFBI for I hour. Immunoblots on whole cell lysates were performed as described in the legend to Figure I, except in the bottom blot an anti-Smad3 antibody was used in place of anti-Smad2/3. Treatments were performed in duplicate. Numbers at the left are molecular weight standards in $\mathrm{kDa}$.

TGFB1 have been noted in other cellular contexts [61,62]. Also, TGFB1 can inhibit its own prototypic signaling via TGFBR1 and Smad2/3, through an ACVRL1 (ALK1)dependent pathway [63]. That is, in addition to complexes containing two TGFBR2 and two TGFBR1 molecules, TGFB1 can form complexes with two TGFBR2, and 


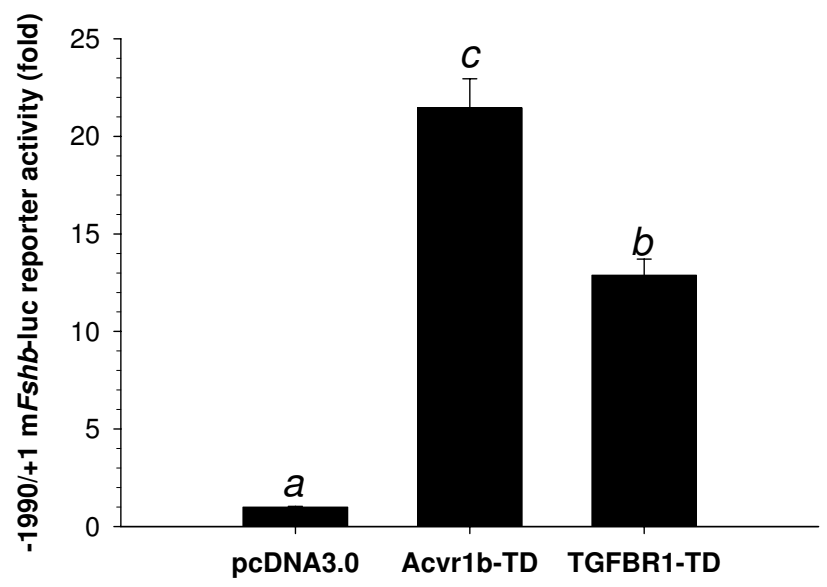

Figure 3

Constitutively active activin and TGFB type I receptors stimulate Fshb transcription in L $\beta T 2$ cells. L $\beta T 2$ cells seeded in 24-well plates were transfected with the 1990/+I mFshb-luc reporter and expression vectors for constitutively active forms of the rat activin (Acvrlb-TD) and human TGFB (TGFBRI-TD) type I receptors or with an empty expression vector (pcDNA3.0). Data reflect mean $(+/$ - SEM) fold-change in luciferase activity from the control condition (pcDNA3.0) in two experiments performed in triplicate $(n=6)$. Bars with different letters differed significantly.

one molecule each of TGFBR1 and ALK1. These latter receptor complexes can stimulate Smad1/5 phosphorylation and thereby inhibit TGFB1 actions mediated via TGFBR1 and Smad2/3 [63]. Whether or not L $\beta$ T2 and/or gonadotropes express ALK1 has not been reported. However, it is possible that ALK1 expression in gonadotropes, but not L $\beta$ T2 cells, may provide a mechanism for TGFB1 to antagonize endogenous activin B-dependent signaling (via Smad2/3) and hence decrease Fshb mRNA levels.

Although gonadotropes were purified to near homogeneity, it is possible that the inhibitory effects of TGFB1 were mediated indirectly through ligand action on contaminating cells in the cultures. For example, TGFB1 might stimulate FST synthesis by folliculostellate cells, which would then suppress the actions of endogenous activin $\mathrm{B}$ in gonadotropes [64]. However, if this were the mechanism of TGFB1 action, one might have anticipated greater inhibitory effects in the mixed rather than purified cultures where there are more folliculostellate cells, but the opposite was actually the case. That is, TGFB1 had greater suppressive activity in purified gonadotropes than in mixed cultures. Moreover, because activins stimulate FST production in primary pituitary cultures [65], one would predict that activin A would be less potent in stimulating

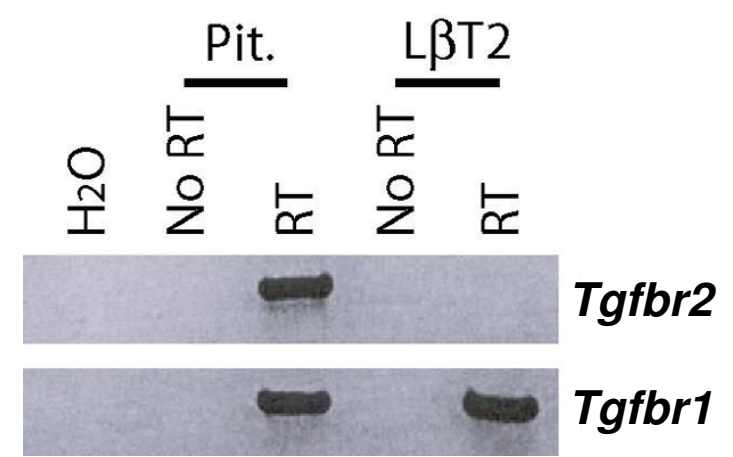

\section{Figure 4}

L $\beta$ T2 cells do not express Tgfbr2 mRNA. RT-PCR analysis of TGFB receptor expression in adult female CD-I murine pituitary gland and L $\beta T 2$ cells. Whereas Tgfbrl mRNA is expressed in both samples (bottom), Tgfbr2 is expressed in whole pituitaries but not in L $\beta$ T2 cells (top). No amplicons were detected in negative control samples (i.e., $\mathrm{H}_{2} \mathrm{O}$ only or no $\mathrm{RT}$ ).

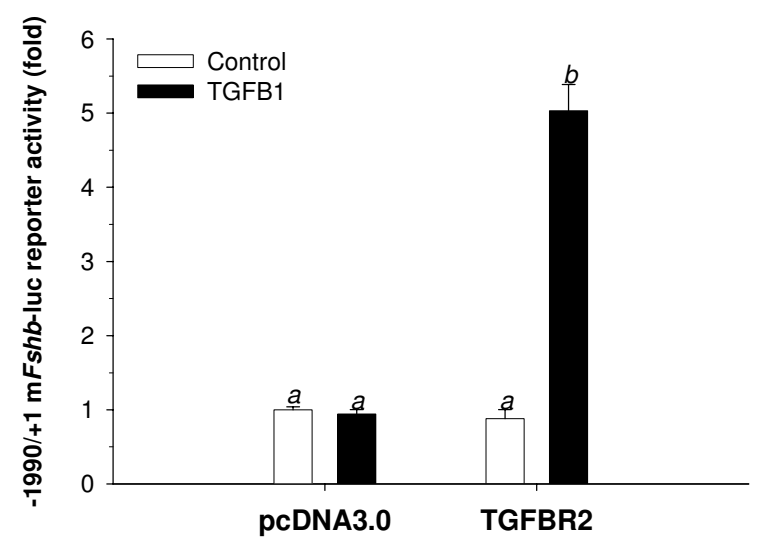

\section{Figure 5}

TGFBR2 over-expression rescues TGFB responsiveness in L $\beta$ T2 2 cells. L $\beta$ T2 cells seeded in 24 -well plates were transfected with the $-1990 /+1 \mathrm{mFshb}$-luc reporter and an expression vector for the human TGFBR2. Control wells were transfected with an empty expression vector, pcDNA3.0. Half of the cells in each condition were then treated with 400 pM TGFBI for approximately $24 \mathrm{hr}$ (filled bars). Data points reflect mean (+/- SEM) fold-change in luciferase activity from the control condition (pcDNA3.0, control) in three experiments performed in triplicate $(n=9)$. Bars with different letters differed significantly. 
A

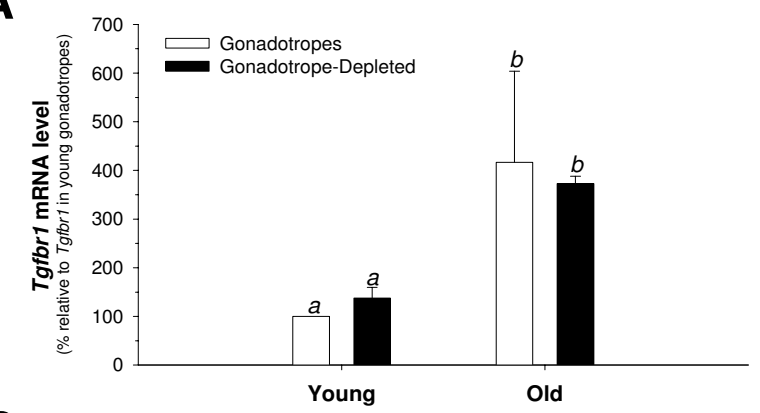

B

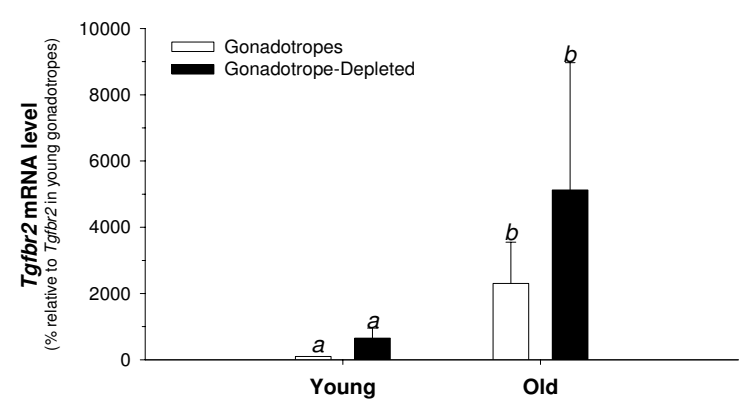

Figure 6

Purified murine gonadotropes express Tgfbr2 at low levels. Purified gonadotropes and gonadotrope-depleted pituitary cells were plated in triplicate in 96 well culture plates. After $48 \mathrm{hrs}$, total RNA was isolated and real-time RT-PCR was performed to examine Tgfbrl and Tgfbr2 mRNA expression. Normalized threshold cycle $(\mathrm{C} t)$ values were averaged and used to compare receptor expression in the different cell types and different age groups using the 2$\Delta \Delta C_{t}$ method for quantitation. Data are presented as mean $(+$ SD) (A) Tgfbrl or (B) Tgfbr2 mRNA levels relative to those in young murine gonadotropes (set to $100 \%$ ). Data from young and old animals were from 3 or 2 independent experiments, respectively. Bars with different letters differed significantly. When averaged across age-groups, Tgfbr2 levels were higher in gonadotrope-depleted cells than in gonadotropes. Note the different scales of the $y$-axes in $(A)$ and $(B)$.

Fshb mRNA levels in mixed than in purified cultures and this was in fact what we observed (Fig. 7). Collectively, these data suggest that the effects of TGFB1 on Fshb mRNA levels are likely not mediated via regulation of FST production, though we cannot rule out that possibility entirely.

The finding that TGFB1 inhibited Fshb expression in primary murine gonadotropes and mixed pituitary cultures is novel, and appears to contrast with data reported previously for the rat and sheep Fshb genes. For example, TGFB was shown to potently and dose-dependently stimulate FSH secretion from rat primary pituitary culture [66].
However, the TGFB preparation used in that study, which was purified from human platelets [67], did not function similarly to recombinant TGFB1 in similar assays $[39,68]$. Subsequent reports have failed to show major effects of TGFB1 on FSH in any dispersed pituitary culture. For example, TGFB1 did not affect ovine Fshb promoterreporter activity in transgenic mice [51] or FSH secretion from rat primary pituitary cultures [39]. In addition, only minor stimulation was observed in primary ovine pituitary cultures [69].

Finally, it is also notable that we observed age-dependent increases in Tgfbr 2 mRNA levels in purified gonadotropes. These data suggest that as mice mature, their gonadotropes may become more sensitive to the effects of TGFBs. The physiological significance, if any, of this change in receptor expression is not yet known, but is the subject of ongoing investigations. These data are nonetheless important in that they suggest that the low levels Tgfbr2 mRNA detected in gonadotropes from young mice are likely not due to contamination by other cell types. Instead, it appears that as gonadotropes age, the level of Tgfbr2 expression increases. Consistent with this notion is the lack of this receptor in L $\beta$ T2 cells, which are thought to represent gonadotropes at an early stage of development. However, L $\beta \mathrm{T} 2$ cells were derived from a female mouse and the purified gonadotropes examined here were all from male mice, so it is possible that differences in Tgfbr2 mRNA levels may also reflect sex differences in receptor expression.

\section{Conclusion}

The data reported here show that immortalized L $\beta$ T2 cells lack the TGFB type II receptor, Tgfbr2, whereas the receptor appears to be expressed and functional in gonadotropes from male mice. As a result, TGFB1 (and likely all TGFB isoforms) is unable to regulate Fshb in L $\beta$ T2 cells, but can inhibit transcription in primary murine gonadotropes. Because activins and TGFBs similarly activate Smads and TAK1, and both pathways contribute to activin A's stimulation of Fshb in rodents, it is surprising that TGFB would produce opposite effects to those of activins in purified gonadotropes. Nonetheless, as predicted, gonadotropes have evolved mechanisms for discriminating between the two classes of ligands. In the future, it will be critical to determine the mechanisms through which TGFBs inhibit Fshb in gonadotropes, particularly as animals age and Tgfbr2 expression increases. Importantly, the data presented here suggest that L $\beta$ T2 cells may not provide the best model system in which to pursue this aspect of FSH regulation.

\section{Competing interests}

The author(s) declare that they have no competing interests. 
A

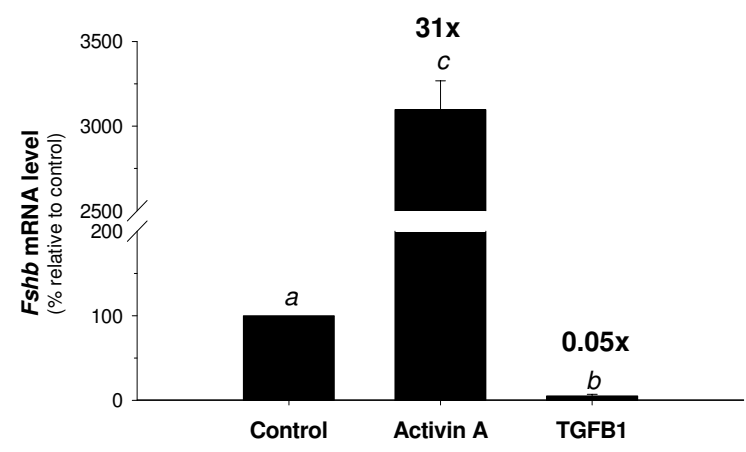

B

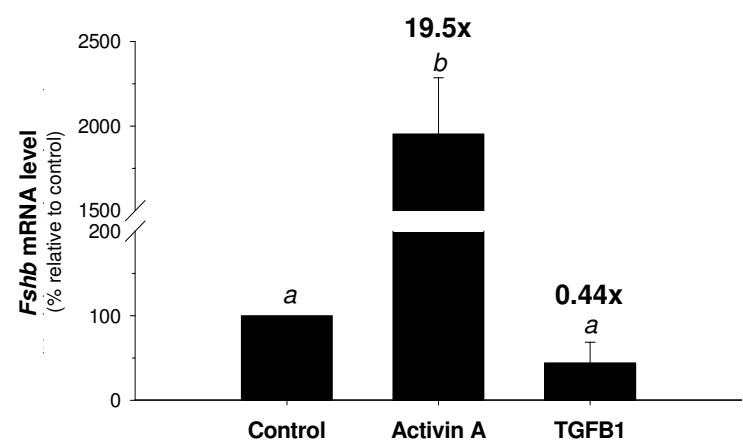

Figure 7

Activin A stimulates, and TGFB I inhibits, Fshb transcription in gonadotropes. Purified gonadotropes $(A)$ or whole pituitary cells $(B)$ were plated in triplicate for control, activin A, or TGFBI treatments in 96 well culture plates. After 24 hrs, cells were pre-treated with follistatin (250 ng/ $\mathrm{ml})$. After $24 \mathrm{hrs}$, all media was removed, and the cells were treated with control media, or media containing either activin A $(60 \mathrm{ng} / \mathrm{ml})$ or TGFBI $(60 \mathrm{ng} / \mathrm{ml})$. After $24 \mathrm{hrs}$ of treatment, total RNA was isolated and real-time RT-PCR was performed. Normalized threshold cycle $(C t)$ values were averaged and used to quantitate Fshb mRNA expression with the $2^{-(\Delta \Delta C t)}$ method for quantitation. The mRNA levels were quantitated relative to the mRNA levels of Fshb in control cells for purified gonadotropes (A) or whole pituitary cells (B), which were normalized to $100 \%$. Plotted are the means $(+/-$ SEM) for three experimental replicates. Bars with different letters differed significantly.

\section{Authors' contributions}

AJG participated in the design of the study, performed all of the gonadotrope purification and real-time RT-PCR analyses, and drafted portions of the manuscript. DPP conducted RT-PCR and receptor expression analyses. WLM participated in the design of the study and critically revised the manuscript. DJB participated in the design of the study, performed many of the transfection and western blot experiments and analyses, and drafted significant portions of the manuscript. All authors read and approved the final manuscript.

\section{Acknowledgements}

The authors thank Dr. Michael Reiss (Robert Wood Johnson Medical School) for the phospho-Smad3 rabbit polyclonal antibody and Dr. Pamela Mellon (UCSD) for the L $\beta$ T2 2 cells. Dr. Joan Massague (Memorial Sloan-Kettering Cancer Center) provided the TGFBR2 and 3TP-luc constructs. The TGFBR I-TD construct was a gift from Dr. Peter Scheiffele (Columbia University). Much of the cell culture work was performed in the Cell and Tissue Culture Core Facility of the Population Council under the direction of Dr. Patricia Morris and with the assistance of Dr. Deborah Lazzarino and Marion Davis. The research was supported by NIH HD44022 and HD047794 to DJB and HD042459 to WLM.

\section{References}

I. Dierich A, Sairam MR, Monaco L, Fimia GM, Gansmuller A, LeMeur $M$, Sassone-Corsi $P$ : Impairing follicle-stimulating hormone (FSH) signaling in vivo: targeted disruption of the FSH receptor leads to aberrant gametogenesis and hormonal imbalance. Proceedings of the National Academy of Sciences of the United States of America 1998, 95:13612-13617.

2. Abel MH, Wootton AN, Wilkins V, Huhtaniemi I, Knight PG, Charlton HM: The effect of a null mutation in the follicle-stimulating hormone receptor gene on mouse reproduction. Endocrinology 2000, I 4 I: I 795-1803.

3. Kumar TR, Wang Y, Lu N, Matzuk MM: Follicle stimulating hormone is required for ovarian follicle maturation but not male fertility. Nature Genetics 1997, 1 5:201-204.

4. Corrigan AZ, Bilezikjian LM, Carroll RS, Bald LN, Schmelzer CH, Fendly BM, Mason AJ, Chin WW, Schwall RH, Vale W: Evidence for an autocrine role of activin $B$ within rat anterior pituitary cultures. Endocrinology I99I, I 28: |682-1684.

5. Baratta M, West LA, Turzillo AM, Nett TM: Activin Modulates Differential Effects of Estradiol on Synthesis and Secretion of Follicle-Stimulating Hormone in Ovine Pituitary Cells. Biol Reprod 2001, 64:714-719.

6. Roberts V, Meunier H, Vaughan J, Rivier J, Rivier C, Vale W, Sawchenko P: Production and regulation of inhibin subunits in pituitary gonadotropes. Endocrinology 1989, I 24:552-554.

7. $\mathrm{Li}$ MD, Macdonald G], Wise T, Ford J]: Positive Association between Expression of Follicle-Stimulating Hormone $B$ and Activin BB-Subunit Genes in Boars. Biol Reprod 1998, 59:978-982

8. Demura R, Suzuki T, Yajima R, Tajima S, Kubo O, Yoshimoto T, Demura $H$ : Inhibin alpha, beta $A$ and beta $B$ subunit messenger ribonucleic acid levels in cultured rat pituitary: studies by a quantitative RT-PCR. Endocrine Journal 1996, 43:403-4I0.

9. DePaolo LV, Bald LN, Fendly BM: Passive immunoneutralization with a monoclonal antibody reveals a role for endogenous activin-B in mediating FSH hypersecretion during estrus and following ovariectomy of hypophysectomized, pituitarygrafted rats. Endocrinology 1992, I 30: I741- I743.

10. Pernasetti F, Vasilyev VV, Rosenberg SB, Bailey JS, Huang HJ, Miller WL, Mellon PL: Cell-specific transcriptional regulation of follicle-stimulating hormone-beta by activin and gonadotropinreleasing hormone in the LbetaT2 pituitary gonadotrope cell model. Endocrinology 200I, I 42:2284-2295.

II. Burger LL, Dalkin AC, Aylor KW, Haisenleder DJ, Marshall IC: GnRH Pulse Frequency Modulation of Gonadotropin Subunit Gene Transcription in Normal Gonadotropes--Assessment by Primary Transcript Assay Provides Evidence for Roles of GnRH and Follistatin. Endocrinology 2002, I 43:3243-3249.

12. Besecke LM, Guendner MJ, Schneyer AL, Bauer-Dantoin AC, Jameson JL, Weiss J: Gonadotropin-releasing hormone regulates follicle-stimulating hormone- beta gene expression through an 
activin/follistatin autocrine or paracrine loop. Endocrinology 1996, I37:3667-3673.

13. Gregory SJ, Lacza CT, Detz AA, Xu S, Petrillo LA, Kaiser UB: Synergy between Activin A and GnRH in Transcriptional Activation of the Rat Follicle-Stimulating Hormone beta (FSH\{beta\}) Gene. Mol Endocrinol 2004:me.2003-473.

14. Burger LL, Haisenleder DJ, Dalkin AC, Marshall JC: Regulation of gonadotropin subunit gene transcription. J Mol Endocrinol 2004, 33:559-584.

I5. Spady TJ, Shayya R, Thackray VG, Ehrensberger L, Bailey JS, Mellon PL: Androgen Regulates Follicle-Stimulating Hormone \{beta\} Gene Expression in an Activin-Dependent Manner in Immortalized Gonadotropes. Mol Endocrinol 2004, I 8:925-940.

16. Harrison CA, Gray PC, Vale WW, Robertson DM: Antagonists of activin signaling: mechanisms and potential biological applications. Trends Endocrinol Metab 2005, I 6:73-78.

17. Thompson TB, Lerch TF, Cook RW, Woodruff TK, Jardetzky TS: The structure of the follistatin:activin complex reveals antagonism of both type I and type II receptor binding. Dev Cell 2005, 9:535-543.

18. Lewis KA, Gray PC, Blount AL, MacConell LA, Wiater E, Bilezikjian LM, Vale W: Betaglycan binds inhibin and can mediate functional antagonism of activin signalling. Nature 2000, 404:4I| $-4 \mid 4$.

19. Martens JW, de Winter JP, Timmerman MA, McLuskey A, van Schaik $\mathrm{RH}$, Themmen AP, de Jong $\mathrm{FH}$ : Inhibin interferes with activin signaling at the level of the activin receptor complex in Chinese hamster ovary cells. Endocrinology 1997, 138:2928-2936.

20. Chapman SC, Bernard DJ, Jelen J, Woodruff TK: Properties of inhibin binding to betaglycan, InhBP/pI20 and the activin type II receptors. Mol Cell Endocrinol 2002, I 96:79-93.

21. Xu J, McKeehan K, Matsuzaki K, McKeehan WL: Inhibin antagonizes inhibition of liver cell growth by activin by a dominantnegative mechanism. J Biol Chem 1995, 270:6308-63। 3.

22. Cook RW, Thompson TB, Kurup SP, Jardetzky TS, Woodruff TK: Structural Basis for a Functional Antagonist in the Transforming Growth Factor \{beta\} Superfamily. J Biol Chem 2005, 280:40177-40186.

23. Matzuk MM, Kumar TR, Bradley A: Different phenotypes for mice deficient in either activins or activin receptor type II. Nature 1995, 374:356-360.

24. Vassalli A, Matzuk MM, Gardner HA, Lee KF, Jaenisch R: Activin/ inhibin beta $B$ subunit gene disruption leads to defects in eyelid development and female reproduction. Genes Dev 1994, 8:4I4-427.

25. Kumar TR, Agno J, Janovick JA, Conn PM, Matzuk MM: Regulation of FSHbeta and GnRH receptor gene expression in activin receptor II knockout male mice. Mol Cell Endocrinol 2003, 21 2:19-27.

26. Thompson TB, Woodruff TK, Jardetzky TS: Structures of an ActRIIB:activin A complex reveal a novel binding mode for TGF-beta ligand:receptor interactions. Embo J 2003, 22:1555-1566.

27. Hart PJ, Deep S, Taylor AB, Shu Z, Hinck CS, Hinck AP: Crystal structure of the human TbetaR2 ectodomain--TGF-beta3 complex. Nat Struct Biol 2002, 9:203-208.

28. Abdollah S, Macias-Silva M, Tsukazaki T, Hayashi H, Attisano L, Wrana JL: TbetaRI phosphorylation of Smad2 on Ser465 and Ser467 is required for Smad2-Smad4 complex formation and signaling. J Biol Chem 1997, 272:27678-27685.

29. Souchelnytskyi S, Tamaki K, Engstrom U, Wernstedt C, ten Dijke P, Heldin CH: Phosphorylation of Ser465 and Ser467 in the C terminus of Smad2 mediates interaction with Smad4 and is required for transforming growth factor-beta signaling. J Biol Chem 1997, 272:28107-28II5.

30. Safwat N, Ninomiya-Tsuji J, Gore AJ, Miller WL: Transforming Growth Factor $\{$ beta\}-Activated Kinase I Is a Key Mediator of Ovine Follicle-Stimulating Hormone \{beta\}-Subunit Expression. Endocrinology 2005, | 46:48|4-4824.

31. Javelaud D, Mauviel A: Crosstalk mechanisms between the mitogen-activated protein kinase pathways and Smad signaling downstream of TGF-beta: implications for carcinogenesis. Oncogene 2005, 24:5742-5750.

32. Bernard DJ: Both SMAD2 and SMAD3 mediate activin-stimulated expression of the follicle-stimulating hormone beta subunit in mouse gonadotrope cells. Mol Endocrinol 2004, 18:606-623.

33. Lamba P, Santos MM, Philips DP, Bernard DJ: Acute regulation of murine follicle-stimulating hormone beta subunit transcription by activin A. J Mol Endocrinol 2005, In press:.

34. Weiss J, Guendner MJ, Halvorson LM, Jameson JL: Transcriptional activation of the follicle-stimulating hormone beta-subunit gene by activin. Endocrinology 1995, I36:1885-1891.

35. Dupont J, McNeilly J, Vaiman A, Canepa S, Combarnous Y, Taragnat C: Activin signaling pathways in ovine pituitary and LbetaT2 gonadotrope cells. Biol Reprod 2003, 68:1877-1887.

36. Norwitz ER, Xu S, Xu J, Spiryda LB, Park JS, Jeong KH, McGee EA, Kaiser UB: Direct binding of AP-I (Fos/Jun) proteins to a SMAD binding element facilitates both gonadotropin-releasing hormone (GnRH)- and activin-mediated transcriptional activation of the mouse GnRH receptor gene. J Biol Chem 2002, 277:37469-37478.

37. Suszko MI, Balkin DM, Chen Y, Woodruff TK: Smad3 Mediates Activin-Induced Transcription of Follicle-Stimulating Hormone \{beta\}-Subunit Gene. Mol Endocrinol 2005, I9: | 849-1858.

38. Burns G, Sarkar DK: Transforming growth factor beta I-like immunoreactivity in the pituitary gland of the rat: effect of estrogen. Endocrinology 1993, I 33:| 444-1449.

39. Sarkar DK, Kim KH, Minami S: Transforming growth factor-beta I messenger RNA and protein expression in the pituitary gland: its action on prolactin secretion and lactotropic growth. Mol Endocrinol 1992, 6:1825-1833.

40. Phillips DJ: Regulation of activin's access to the cell: why is mother nature such a control freak? Bioessays 2000, 22:689-696

41. Woodruff TK, Krummen LA, Lyon RJ, Stocks DL, Mather JP: Recombinant human inhibin $A$ and recombinant human activin $A$ regulate pituitary and ovarian function in the adult female rat. Endocrinology 1993, I32:2332-2341.

42. Woodruff TK, Besecke LM, Groome N, Draper LB, Schwartz NB, Weiss J: Inhibin A and inhibin B are inversely correlated to follicle-stimulating hormone, yet are discordant during the follicular phase of the rat estrous cycle, and inhibin $A$ is expressed in a sexually dimorphic manner. Endocrinology 1996, I 37:5463-5467.

43. Welt CK, Pagan YL, Smith PC, Rado KB, Hall JE: Control of FollicleStimulating Hormone by Estradiol and the Inhibins: Critical Role of Estradiol at the Hypothalamus during the Luteal-Follicular Transition. J Clin Endocrinol Metab 2003, 88: I766-I77I.

44. Welt CK, Hall JE, Adams JM, Taylor AE: Relationship of Estradiol and Inhibin to the Follicle-Stimulating Hormone Variability in Hypergonadotropic Hypogonadism or Premature Ovarian Failure. I Clin Endocrinol Metab 2005, 90:826-830.

45. Halvorson LM, Weiss J, Bauer-Dantoin AC, Jameson JL: Dynamic regulation of pituitary follistatin messenger ribonucleic acids during the rat estrous cycle. Endocrinology I994, I34: | 247-I 253.

46. Besecke LM, Guendner MJ, Sluss PA, Polak AG, Woodruff TK, Jameson JL, Bauer-Dantoin AC, Weiss J: Pituitary Follistatin Regulates Activin-Mediated Production of Follicle-Stimulating Hormone during the Rat Estrous Cycle. Endocrinology 1997, 1 38:2841-2848.

47. Chapman SC, Woodruff TK: Modulation of activin signal transduction by inhibin B and inhibin-binding protein (InhBP). Mol Endocrinol 200 I, I 5:668-679.

48. Gonzalez-Manchon C, Vale W: Activin-A, inhibin and transforming growth factor-beta modulate growth of two gonadal cell lines. Endocrinology 1989, I25: I666- I672.

49. Nakamura T, Takio K, Eto Y, Shibai H, Titani K, Sugino H: Activinbinding protein from rat ovary is follistatin. Science 1990, 247:836-838

50. Wu JC, Su P, Safwat NW, Sebastian J, Miller WL: Rapid, Efficient Isolation of Murine Gonadotropes and Their Use in Revealing Control of Follicle-Stimulating Hormone by Paracrine Pituitary Factors. Endocrinology 2004, I 45:5832-5839.

5I. Huang HJ, Sebastian J, Strahl BD, Wu JC, Miller WL: The promoter for the ovine follicle-stimulating hormone-beta gene (FSHbeta) confers FSHbeta-like expression on luciferase in transgenic mice: regulatory studies in vivo and in vitro. Endocrinology 200I, I 42:2260-2266. 
52. Livak KJ, Schmittgen TD: Analysis of relative gene expression data using real-time quantitative PCR and the 2-DDCt method. Methods 200I, 25:402-408.

53. Wrana JL, Attisano L, Carcamo J, Zentella A, Doody J, Laiho M, Wang $X F$, Massague J: TGF beta signals through a heteromeric protein kinase receptor complex. Cell 1992, 71:1003-1014.

54. Attisano L, Wrana JL, Montalvo E, Massague J: Activation of signalling by the activin receptor complex. Mol Cell Biol 1996, 16:1066-1073.

55. Wieser R, Wrana JL, Massague J: GS domain mutations that constitutively activate $T$ beta $R-I$, the downstream signaling component in the TGF-beta receptor complex. Embo J 1995, I 4:2199-2208.

56. Yu L, Hebert MC, Zhang YE: TGF-beta receptor-activated p38 MAP kinase mediates Smad-independent TGF-beta responses. Embo / 2002, 21:3749-3759.

57. Alarid ET, Windle JJ, Whyte DB, Mellon PL: Immortalization of pituitary cells at discrete stages of development by directed oncogenesis in transgenic mice. Development 1996, 1 22:3319-3329.

58. Sarkar DK, Pastorcic M, De A, Engel M, Moses H, Ghasemzadeh MB: Role of transforming growth factor (TGF)-beta Type I and TGF-beta type II receptors in the TGF-beta I-regulated gene expression in pituitary prolactin-secreting lactotropes. Endocrinology 1998, 139:3620-3628.

59. De A, Morgan TE, Speth RC, Boyadjieva N, Sarkar DK: Pituitary lactotrope expresses transforming growth factor beta (TGF beta) type II receptor mRNA and protein and contains I 25ITGF beta I binding sites. J Endocrinol 1996, 149:19-27.

60. Suszko MI, Lo DJ, Suh H, Camper SA, Woodruff TK: Regulation of the rat follicle-stimulating hormone beta-subunit promoter by activin. Mol Endocrinol 2003, 17:3 |8-332.

61. Song Y, Keelan J, France JT: Activin-A stimulates, while transforming growth factor beta I inhibits, chorionic gonadotrophin production and aromatase activity in cultured human placental trophoblasts. Placenta 1996, 17:603-610.

62. Hutchinson LA, Findlay JK, de Vos FL, Robertson DM: Effects of bovine inhibin, transforming growth factor-beta and bovine Activin-A on granulosa cell differentiation. Biochem Biophys Res Commun 1987, 146:1405-14/2.

63. Goumans MJ, Valdimarsdottir G, Itoh S, Lebrin F, Larsson J, Mummery C, Karlsson S, ten Dijke P: Activin receptor-like kinase (ALK) I is an antagonistic mediator of lateral TGFbeta/ALK5 signaling. Mol Cell 2003, I 2:817-828.

64. Bilezikjian LM, Blount AL, Leal AM, Donaldson CJ, Fischer WH, Vale WW: Autocrine/paracrine regulation of pituitary function by activin, inhibin and follistatin. Mol Cell Endocrinol 2004, 225:29-36.

65. Bilezikjian LM, Corrigan AZ, Vaughan JM, Vale WM: Activin-A regulates follistatin secretion from cultured rat anterior pituitary cells. Endocrinology 1993, 133:2554-2560.

66. Ying SY, Becker A, Baird A, Ling N, Ueno N, Esch F, Guillemin R: Type beta transforming growth factor (TGF-beta) is a potent stimulator of the basal secretion of follicle stimulating hormone (FSH) in a pituitary monolayer system. Biochem Biophys Res Commun 1986, 135:950-956.

67. Assoian RK, Komoriya A, Meyers CA, Miller DM, Sporn MB: Transforming growth factor-beta in human platelets. Identification of a major storage site, purification, and characterization. J Biol Chem 1983, 258:7155-7|60.

68. Murata T, Ying SY: Transforming growth factor-beta and activin inhibit basal secretion of prolactin in a pituitary monolayer culture system. Proc Soc Exp Biol Med 1991, 198:599-605.

69. Chaidarun SS, Eggo MC, Stewart PM, Barber PC, Sheppard MC: Role of growth factors and estrogen as modulators of growth, differentiation, and expression of gonadotropin subunit genes in primary cultured sheep pituitary cells. Endocrinology 1994 , 1 34:935-944.

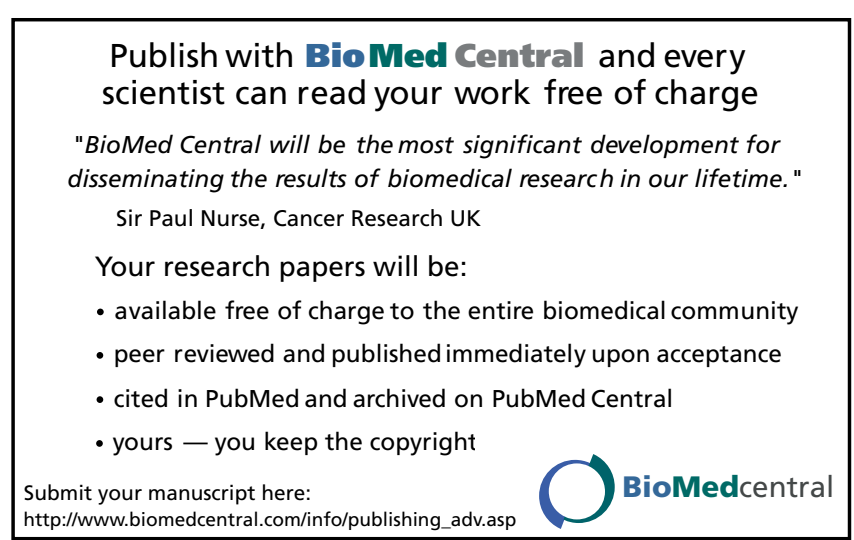

